\title{
Effects of invasive wetland macrophytes on habitat selection and movement by freshwater turtles
}

\author{
Siow Yan Jennifer Angoh (D) J Joanna Freeland (1D - James Paterson $(\mathbb{D} \cdot$ \\ Prabha Amali Rupasinghe ${ }^{(D)}$ Christina M. Davy $(\mathbb{D}$
}

Received: 31 July 2020/Accepted: 20 March 2021/Published online: 11 April 2021

(C) The Author(s) 2021

\begin{abstract}
Invasive species can significantly impact native wildlife by structurally altering habitats and access to resources. Understanding how native species respond to habitat modification by invasive species can inform effective habitat restoration, avoiding inadvertent harm to species at risk. The invasive graminoids Phragmites australis australis (hereafter Phragmites) and Typha $\times$ glauca are increasingly dominating Nearctic wetlands, often outcompeting native vegetation. Previous research suggests that turtles may avoid invasive Phragmites when moving through their home ranges, but the mechanisms driving avoidance are unclear. We tested two hypotheses that could explain avoidance of invaded habitat: (1) that stands of invasive macrophytes (Phragmites and Typha $x$ glauca) impede movement, and (2) that
\end{abstract}

Supplementary Information The online version contains supplementary material available at https://doi.org/10.1007/ s10530-021-02505-8.

S. Y. J. Angoh $(\bowtie) \cdot$ J. Freeland · J. Paterson ·

C. M. Davy ( $\bowtie)$

Environmental and Life Sciences Program, Trent

University, Peterborough, ON K9H 7B8, Canada

e-mail: jenniferangoh@trentu.ca

C. M. Davy

e-mail: christina.davy@ontario.ca

J. Freeland

e-mail: joannafreeland@trentu.ca

J. Paterson

e-mail: jamespaterson@trentu.ca they provide inadequate thermal conditions for turtles. We quantified active-season movements of E. blandingii ( $\mathrm{n}=14,1328$ relocations) and spotted turtles (Clemmys guttata; $\mathrm{n}=12,2295$ relocations) in a coastal wetland in the Laurentian Great Lakes. Neither hypothesis was supported by the data. Phragmites and mixed-species Typha stands occurred within the home ranges of mature, active E. blandingii and $C$. guttata, and were used similarly to most other available habitats, regardless of macrophyte stem density. Turtles using stands of invasive macrophytes did not experience restricted movements or cooler shell temperatures compared to other wetland habitat types. Control of invasive macrophytes can restore habitat heterogeneity and benefit native wetland species. However, such restoration work should be informed by the presence of at-risk turtles, as heavy machinery used for control or removal may injure turtles that use these stands as habitat.

\author{
P. A. Rupasinghe \\ Department of Biology, McMaster University, Hamilton, \\ ON L8S 4K1, Canada \\ e-mail: rupasinp@mcmaster.ca \\ C. M. Davy \\ Wildlife Research and Monitoring Section, Ontario \\ Ministry of Natural Resources and Forestry, \\ Peterborough, ON K9J 7B8, UK
}


Keywords Emydoidea blandingii $\cdot$ Clemmys guttata $\cdot$ Species at risk - Invasive plants $\cdot$ Phragmites australis $\cdot$ Typha $\times$ glauca

\section{Introduction}

Invasive species threaten biodiversity through habitat alteration, increased predation pressure, and competition with native species (Wilcove et al 1998; Sala et al 2000; Gaertner et al 2009; Vilà et al 2011; Early et al 2016; Dueñas et al 2018). Range expansions of invasive wetland plants, such as Lythrum salicaria, Typha $\times$ glauca, Myriophyllum spicatum, Phalaris arundinacea, and Phragmites australis australis have dramatically modified many Nearctic wetlands (Galatowitsch et al 1999). By outcompeting native flora, invasive wetland macrophytes can influence plant species richness and composition, but they may also affect trophic interactions and habitat quality for wetland faunas (Chambers et al 1999; Keller 2000; Levine et al 2003; Minchinton and Bertness 2003; Minchinton et al 2006). Understanding whether endangered, native faunas can persist in wetland habitats that are modified by invasive plants is essential for accurately predicting the future impacts of invasive plants, and for prioritizing control actions. This requires a mechanistic understanding of how invasive species affect the behaviours of the native species that encounter them (Stewart et al 2021).

Palearctic Phragmites australis australis is a robust graminoid that has been spreading through Nearctic wetlands since its introductions to eastern North America in the late 1800s (Van Der Putten 1997; Chambers et al 1999; Orson 1999; Tulbure et al 2007; Vilà et al 2010; Hirtreiter and Potts 2012; Kiviat 2013). A native, non-invasive subspecies, Phragmites australis americanus, also occurs in Nearctic wetlands (Orson 1999; Saltonstall et al 2004), but the invasive $P$. a. australis (hereafter "Phragmites") is now the dominant lineage in many areas of North America including regions surrounding the Laurentian Great Lakes (LGL) (Saltonstall 2002; Tulbure and Johnston 2010; Kirk et al 2011b; Meyerson and Cronin 2013). In wetlands where it is well established, Phragmites affects habitat structure and connectivity by altering vegetation composition, hydrology, canopy structure, and microclimates (Weinstein and Balletro 1999).
Phragmites stands can be extremely dense, with up to 100 live culms per square meter and heights of up to four meters; these dense stands can maintain relatively cool temperatures close to soil and water surfaces in wetlands (Windham and Meyerson 2003; Rogalski and Skelly 2012; Mifsud 2014).

Across much of its introduced range, invasive Phragmites is broadly sympatric with Typha, which in Canada and the northern USA comprises native Typha latifolia L., introduced T. angustifolia L., and their hybrid T. $\times$ glauca (Godr.) (Galatowitsch et al 1999; Ciotir et al 2013; Ciotir and Freeland 2016). In regions surrounding the LGL and St. Lawrence Seaway, T. $\times$ glauca is considered invasive because it can outcompete its progenitor species (Frieswyk and Zedler 2007; Larkin et al 2012; Freeland et al 2013), and often forms dense stands that can significantly modify abiotic and biotic habitat characteristics such as water depth, nutrient concentration, species abundance and species richness (e.g. Tulbure et al. 2007; Tuchman et al. 2009; Bellavance and Brisson 2010; Lishawa et al. 2010; Mitchell et al. 2011; Hirtreiter and Potts 2012). In recent decades $T . \times$ glauca has invaded wetlands in the LGL region (Farrer and Goldberg 2009; Tuchman et al 2009; Lishawa et al 2010; Mitchell et al 2011; Geddes et al 2014; Bansal et al 2019), and is now the dominant Typha in those areas even though it often co-exists with one or both of its progenitor species (Travis et al 2010; Kirk et al 2011a; Freeland et al 2013; Pieper et al 2020). As a result, Typha stands around the LGL have been substantially modified over the past few decades, and we hereafter refer to stands that typically comprise mixed Typha species and hybrids as 'Typha'.

Evidence for the impact of invasive Phragmites and Typha on Nearctic wetland faunas is equivocal (Bernstein and Mclean 1980; Kantrud 1986; Weis and Weis 2003; Hershner and Havens 2008; Martin and Blossey 2013; Gagnon Lupien et al 2015; Robichaud and Rooney 2017). Fowler's toad (Anaxyrus fowleri) abundance declined following Phragmites invasion in a coastal wetland (Greenberg and Green 2013), but that invasion co-occurred with other habitat alterations that may also have affected toad abundance. Abundance and diversity of invertebrates and waterfowl is lower in monodominant stands of Typha compared to wetland habitats with higher heterogeneity (Kantrud 1986; Linz et al 1996b, 1999; Lishawa et al 2010), and abundance 
and diversity of birds are lower in Phragmites stands compared to native marsh habitats (Kantrud 1986; Benoit and Askins 1999; Robichaud and Rooney 2017). In contrast, dense Typha stands provide suitable roosting habitats for some bird species including red-winged blackbirds (Agelaius phoeniceus), yellowheaded blackbirds (Xanthocephalus xanthocephalus) and marsh wrens (Cistothorus palustris) (Linz et al 1996a; Linz and Homan 2011). Typha also provides food and cover for some mammals (e.g. muskrats, Ondatra zibethicus) (Boyce 1978; Grace and Harrison 1986; Campbell and MacArthur 1994), although it is unclear whether this is true of both native and invasive Typha. Invasive Phragmites stands provide habitat for native species such as mummichog (Fundulus heteroclitus; Fell et al. 1998), other freshwater fish (Wynia 2019), and American bullfrog (Lithobates catesbeianus; Rogalski and Skelly 2012).

As the ranges of invasive Phragmites and T. $\times$ glauca expand, understanding their effects on endangered turtles is crucial for mitigating the inadvertent effects of control measures for invasive macrophytes. Habitat restoration efforts in Canada and the United States currently control invasive Phragmites with measures that include herbicide applications (typically glyphosate-based products), mechanical rolling of stands, cutting and removal, and/or burning (Kettenring and Adams 2011; Wagner et al 2017; Quirion et al 2018). Typha $\times$ glauca is controlled in the United States with some of the same methods (Linz and Homan 2011; Lawrence et al 2016). If habitats dominated by invasive Phragmites or Typha are not suitable for endangered turtles, then controlling these macrophytes may be a priority for recovery of endangered turtle populations. For example, the range of invasive Phragmites is expected to completely overlap with the Canadian ranges of Blanding's turtle (Emydoidea blandingii) and spotted turtle (Clemmys guttata) by 2030 (Catling and Mitrow 2011; Environment and Climate Change Canada 2018a; Environment and Climate Change Canada 2018b), and both species are listed as globally endangered by the International Union for the Conservation of Nature (van Dijk 2011; van Dijk and Rhodin 2011). Conversely, if turtles do not avoid these invasive-dominated habitats, then careful planning of macrophyte control is essential to minimize risk to resident turtles, while slowing invasion by non-native plant species.
There has been relatively little investigation into whether turtles actively avoid stands of large, invasive macrophytes, although tracking of Blanding's turtles in two coastal wetlands revealed dynamic home ranges (i.e. home ranges can shift among years), and suggested that turtles did not avoid Phragmites when selecting their home ranges (i.e. second-order habitat selection, sensu Johnson 1980; Markle and ChowFraser 2018). However, at the individual level (thirdorder selection; Johnson 1980), males and non-gravid females avoided untreated Phragmites stands within their home range (Markle and Chow-Fraser 2018). Turtles did not avoid Typha, despite structural similarities between Typha and Phragmites stands (Farnsworth and Meyerson 2003; Paradis et al 2014).

The high shoot densities and substantial litter accumulation in Phragmites and T. $\times$ glauca stands (Tulbure et al 2007; Vaccaro et al 2009; Holdredge and Bertness 2011; Larkin et al 2012) could restrict movement of turtles. These dense stands could also reduce access to essential resources such as basking sites, food, and protective cover, and even affect nest success by invading and shading previously unshaded nesting sites (Bolton and Brooks 2010; COSEWIC 2016a; Cook et al 2018; Environment and Climate Change Canada 2018b). Markle and Chow-Fraser (2018) hypothesized that the individual-level avoidance of Phragmites by E. blandingii may have arisen because Phragmites either obstructs the movements of turtles, or provides inadequate thermal conditions.

The objective of our study was to directly test these two hypotheses: that stands of invasive macrophytes (Phragmites and Typha spp.) are barriers to movement and provide inadequate thermal conditions for turtles. Assumed support for these hypotheses is implicit in recent conservation status assessments for E. blandingii and the sympatric, highly endangered $C$. guttata (COSEWIC 2014, 2016b). Clemmys guttata is much smaller than E. blandingii, and we speculated that it might therefore be better able to navigate dense macrophyte stands. We used GPS tracking to collect hourly or bi-hourly relocations from $E$. blandingii and C. guttata across $\sim 70$ days in the peak active season of the two species. We used these high-resolution datasets to quantify fine-scale movement and habitat use of each species in a wetland mosaic that included stands of invasive Phragmites and Typha. We predicted that if Phragmites and Typha stands were barriers to movement, turtle movements through 
Phragmites or Typha would be slower than movements through other habitat types, and turtle movements through invasive macrophyte stands would have higher relative turning angles compared to movements in other habitat types (i.e. if macrophytes are barriers then they should impede navigation). We predicted that if the stands act as barriers or provide inadequate thermal conditions, then turtles moving through their home ranges would avoid habitats dominated by these macrophytes when selecting locations within a homerange, and would select microhabitats with lower densities of Phragmites and Typha shoots than they would encounter if moving randomly. Finally, we compared shell temperatures of turtles that were using Phragmites and Typha stands to those of turtles using uninvaded habitats in order to test the hypothesis that Phragmites and Typha stands interfere with a turtle's ability to thermoregulate due to increased shading. Our study fills critical knowledge gaps to inform adaptive management of endangered turtle populations during biological invasions of wetlands.

\section{Materials and methods}

\section{Characterization of available habitat}

We conducted this study in a coastal wetland $(\sim 8.31$ $\mathrm{km}^{2}$ ) on the north shore of Lake Erie, Ontario, Canada, one of the Laurentian Great Lakes ("Site A" in Markle and Chow-Fraser 2018). The wetland is a mosaic of habitat dominated by Typha and Phragmites, interspersed among open meadow marsh, forested areas, and a coastal dune system. To confirm that Typha stands at this site include the invasive hybrid $T$. $\times$ glauca, we collected 45 pollen samples from dehiscent staminate spikes at six locations across the study site on 28 June and 3 July 2019. We examined pollen grains under a compound microscope at $40 \times$ magnification to identify plants as either T. latifolia (tetrad pollen grains; Online Resource 1; Fig. S1), T. angustifolia (monad pollen grains; Online Resource 1; Fig. S1) or $T$. $\times$ glauca (mixture of pollen grain types, including tetrads and monads; Online Resource 1; Fig. S1) (Krattinger 1975).

We used WorldView 2 multispectral satellite imagery (1.8 $\mathrm{m}$ spatial resolution, 8 multispectral bands) acquired on $5^{\text {th }}$ September 2018 to map the habitat types using ENVI 5.5 (Exelis Visual
Information Solutions, Boulder, CO). We used maximum likelihood classification to map seven habitat types: meadow marsh, Typha-dominated marsh, forest, open land, open water, Phragmites-dominated marsh, and shrub (see Table 1 for habitat descriptions). There have been efforts to control Phragmites at the study site, and the classification of Phragmites-dominated habitats included areas where Phragmites had been sprayed in previous years (but not rolled or burned). For the image classification and accuracy assessment, we used ground reference locations from vegetation surveys conducted in July and August 2018 (further details provided below), and from visual interpretations of high-resolution satellite imagery (pansharpened WorldView 2; $50 \mathrm{~cm}$ ). We used only 192 out of 810 sampling locations collected in the field for this purpose, because these were the locations that had one land cover class covering over $80 \%$ of a $4 \mathrm{~m}^{2}$ vegetation survey quadrat (details of vegetation surveys are provided below). For the image classification, we used 100 locations from the field data and 98 locations from image interpretation. We used 92 of the ground-reference locations plus 233 locations selected from high-resolution image interpretation as test locations to assess the accuracy of the image classification. The test locations gave an overall accuracy of $84.27 \%$ for the image classification which allowed us to proceed with further analyses.

\section{Telemetry}

Turtles were captured between 2 May and 21 June 2018 either using baited hoop and minnow traps (Memphis Net and Twine Company, Memphis, Tennessee, USA), or hand-capturing along line transects. Trapping sites and transects targeted all available habitat types that contained standing water, including stands of Phragmites and Typha, marsh meadow, and open water areas.

We affixed dual, very high frequency, global positioning system (VHF-GPS) transmitters (Pinpoint VHF 120 and 240; Lotek Inc., Newmarket, Ontario, Canada) to the rear costal scutes of turtles using epoxy (J-B Weld WaterWeld, J-B Weld Company, Texas, USA; Fig. 1). Turtles weighing $<180 \mathrm{~g}$ were outfitted with a $5 \mathrm{~g}$ Pinpoint120 (GPS location taken and archived every $60 \mathrm{~min}$ when the transmitter antenna was exposed). Heavier turtles ( $\geq 180 \mathrm{~g}$ ) were outfitted with a 7 g Pinpoint 240 (GPS locations archived every 
Table 1 Habitat classification within the minimum convex polygon of tracked Emydoidea blandingii (Blanding's turtles; $\mathrm{n}=14$ ) and Clemmys guttata (spotted turtles; $\mathrm{n}=12$ ) in a coastal wetland in the Laurentian Great Lakes

\begin{tabular}{|c|c|c|c|c|c|}
\hline \multirow{2}{*}{$\begin{array}{l}\text { Habitat } \\
\text { type }\end{array}$} & \multirow[t]{2}{*}{ Description } & \multicolumn{2}{|c|}{ E. blandingii } & \multicolumn{2}{|c|}{ C. guttata } \\
\hline & & $\begin{array}{l}\text { Area } \\
\left(\mathrm{m}^{2}\right)\end{array}$ & Proportion & $\begin{array}{l}\text { Area } \\
\left(\mathrm{m}^{2}\right)\end{array}$ & Proportion \\
\hline Typha & $\begin{array}{l}>70 \% \text { cover of Typha }(\operatorname{mix} \text { of } T . \text { angustifolia, } T \text {. latifolia and } \\
T . \times \text { glauca }) \text { with homogenous appearance }\end{array}$ & $1,117,285$ & 0.21 & 659,150 & 0.30 \\
\hline $\begin{array}{l}\text { Meadow } \\
\text { marsh }\end{array}$ & $>25 \%$ cover of low-growing rushes and sedge hummocks & $1,065,505$ & 0.20 & 584,616 & 0.26 \\
\hline Forest & $\begin{array}{l}\text { Terrestrial habitat dominated by coniferous or deciduous trees }>2 \mathrm{~m} \\
\text { tall with at least } 50 \% \text { canopy cover }\end{array}$ & 928,634 & 0.17 & 118,615 & 0.05 \\
\hline Open land & $\begin{array}{l}\text { Includes terrestrial habitat dominated by low-growing herbaceous } \\
\text { vegetation, sand beaches and anthropogenic land uses such as } \\
\text { campgrounds, roads, and trails }\end{array}$ & 61,786 & 0.01 & 16,889 & 0.008 \\
\hline $\begin{array}{l}\text { Open } \\
\text { water }\end{array}$ & Water bodies with $<25 \%$ vegetation cover & 819,975 & 0.15 & 401,887 & 0.18 \\
\hline Phragmites & $\begin{array}{l}>70 \% \text { cover of Phragmites (including stands of dead Phragmites } \\
\text { that have been previously sprayed with herbicides) }\end{array}$ & 663,810 & 0.12 & 247,012 & 0.11 \\
\hline Shrub & $\begin{array}{l}>25 \% \text { short bushy vegetation (e.g., button bush, Cephalanthus } \\
\text { occidentalis) }\end{array}$ & 776,898 & 0.14 & 193,590 & 0.09 \\
\hline
\end{tabular}

30 min when the transmitter antenna was exposed). Transmitters archived a temperature measurement alongside each GPS location, and at scheduled times (every 30 or $60 \mathrm{~min}$ ) even where the GPS location could not be taken (i.e. the turtle was underwater or under cover at the scheduled location time). Total attachment weight for E. blandingii (transmitter plus attachment and epoxy) weighed $0.6-5 \%$ of the turtles' body mass (mean: $2 \%$ of body mass). Total attachment weight for C. guttata ranged from $4-6 \%$ of the turtles' body weight (mean: $5 \%$ of body weight).
We located turtles every 1-3 weeks, using a 3-element Yagi antenna (Lotek Inc.) and a Communication Specialists receiver (Communication Specialists Inc., Orange, California, USA) to download archived GPS data. We also replaced the transmitter on located turtles with a fully charged unit. We tracked each turtle from its capture date until its transmitter stopped functioning.

We fitted 27 E. blandingii and 17 C. guttata with transmitters. Unfortunately, the transmitters stopped functioning earlier than predicted by the manufacturer,
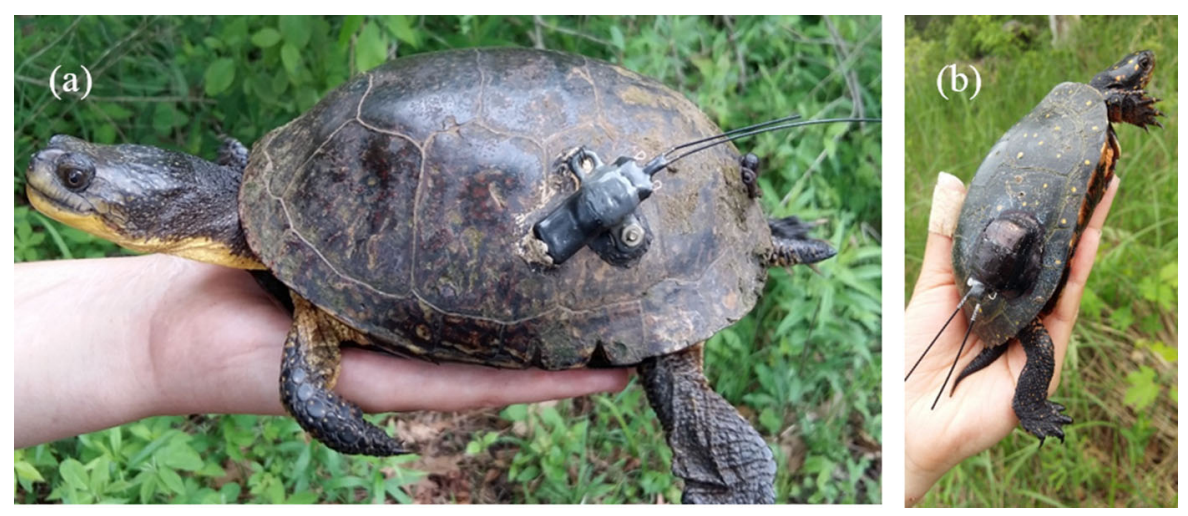

Fig. 1 An Emydoidea blandingii (Blanding's turtle) (a) and a Clemmys guttata (spotted turtle) (b) with dual VHF-GPS transmitter attached to rear costal scutes 
precluding us from continuing the study into hibernation as initially planned, and from using data from all 44 turtles that were fitted with transmitters. We collected movement data between 2 May and 12 July 2018. Searches of wetland habitat within turtles' home ranges were used to recapture turtles after their tags ceased functioning, and to remove non-functional transmitters.

We estimated home range kernels for $14 E$. blandingii (7 males and 7 females; 15-416 relocations/individual; mean $\pm \mathrm{SE}: 95 \pm 35$ relocations/turtle), and 12 C. guttata (7 males and 5 females; 38-516 relocations/individual; mean \pm SE: $191 \pm 43$ relocations/turtle). Data spanned a range of 11-59 days/individual for E. blandingii (1328 total relocations), and 9-58 days/individual for $C$. guttata (2295 total relocations). The mean time difference between relocations was $4.5 \mathrm{~h}$ (range $0.5-336 \mathrm{~h}$ ).

\section{Habitat selection}

We analyzed habitat selection using the package 'adehabitatHR' (Calenge 2006) in R 3.3.1 (R Core Team 2018) and ArcMap 10.6.1 (ESRI 2018). We explored habitat selection independently for $E$. blandingii and $C$. guttata and considered two spatial scales. Landscape scale habitat selection (2nd order selection, Johnson 1980) described selection of home ranges within the available habitat (Aebisher et al 1993; Rasmussen and Litzgus 2010). At this scale, we quantified home ranges (Aebisher et al 1993) by creating home range kernels for each turtle that had $\geq 15$ relocations (GPS locations; $\mathrm{n}=14 \mathrm{E}$. blandingii and 12 C. guttata). We used the method of Row and Blouin-Demers (2006) to select an appropriate smoothing function for the kernels. We delineated minimum available habitat for each species at the study site by creating a minimum convex polygon around all the turtle relocations obtained from GPS-tracking locations. Next, we simulated comparable home ranges that reflected available habitat. We simulated 20 "available habitat kernels" per turtle in ArcMap 10.6.1 (ESRI 2018) by creating polygons of the same size and shape as the actual home range kernels previously calculated for each turtle. We used the 'Create random points' tool in ArcMap 10.6.1 to locate centroids of available habitat kernels randomly in the minimum available habitat. We calculated the proportions of different habitat types in the actual home range kernels and the simulated, available habitat kernels using the dissolve tool and field calculator in ArcMap 10.6.1 (ESRI 2018).

We also examined home-range-scale habitat selection (3rd order selection; Johnson 1980). At this scale, we defined used habitats as those habitats in which turtles were located within individual home range kernels (Aebisher et al 1993; Rasmussen and Litzgus 2010). We defined available habitats as the habitats within home range kernels of each turtle (Aebisher et al 1993). We compared the proportion of relocations of each individual of each species in each used habitat (number of relocations in each habitat / total number of relocations in that turtle's home range kernel) with the availability of each habitat (proportion of the turtle's home range kernel represented by each habitat type).

We calculated Manly's selection ratios (Manly et al 2002; Calenge and Dufour 2006) for each individual to describe the use of each habitat type in the home range relative to its availability in the minimum available habitat (landscape scale selection). Selection ratios ( \pm confidence intervals, $\mathrm{CI}$ ) between 0 and 1 indicate a habitat type used less than its availability (avoidance), while selection ratios $( \pm \mathrm{CI})>1$ indicate habitat preference. Habitat types with a selection ratio ( $\pm \mathrm{CI}$ ) including 1 are neither avoided nor preferred (Calenge and Dufour 2006). We used Manly's selection ratios to quantify home-range-scale habitat selection by comparing used locations for each individual to habitats available within its home range.

To ensure our conclusions were not a consequence of our choice of analyses, we also compared used and available habitats using compositional analyses (Aebisher et al 1993) and Eigen analyses of selection ratios ('adehabitatHS'; Calenge and Dufour 2006), summarized in the Online Resource 1.

\section{Microhabitat selection}

To investigate the impact of macrophyte shoot density on microhabitat selection, we compared Phragmites and Typha shoot densities at locations used by each turtle to shoot densities at randomly selected locations within its home range. We used the R packages 'sp' (Pebesma and Bivand 2005) and 'tripack' (Renka et al 2020) to randomly select 10-15 GPS locations for each turtle, with a horizontal dilution of precision $<2$. For turtles with more than 15 GPS points, we 
randomly sampled 15 GPS locations and 15 random locations evenly distributed across an individual home range. For turtles with fewer than 15 GPS points, we used every location and randomly sampled an equal number of random locations evenly distributed across an individual home range. We counted the number of Phragmites and Typha stems and recorded \% cover of other vegetation types within a $4 \mathrm{~m}^{2}$ quadrat centered at each used and random location.

We compared the densities of Phragmites and Typha shoots in used and random locations with binomial generalized linear mixed models (GLMM, 'Ime4' package, Bates et al. 2015). We ran an independent model for each species. Each model included a binary response variable (used or random location), a random factor (turtle ID, to account for the underlying variance in vegetation between different turtle home ranges), and fixed main effects of Phragmites density, Typha density, and their interaction.

\section{Movement}

Turtle movement speed could differ among marsh habitat types if it is physically more challenging for turtles to move through dense vegetation, or if turtle behaviour differs among habitats. If turtles avoid particular habitats, then we might also expect different trajectories in some habitats compared to others. We built trajectories for each turtle by connecting consecutive locations to quantify "steps". We used GLMMs to test whether turtles' movement speeds $(\mathrm{m} / \mathrm{hr}$ ) and turning angles (in radians, relative to previous step) differed in Phragmites or Typha patches compared to other habitats. We used separate models for each species and response (step speed and turning angle). We used only locations collected between 06:00 and 21:00, because nocturnal step lengths were biased towards zero. In our analyses for each turtle, we included only those steps for which the difference in time between locations was $<4 \mathrm{~h}$. This approach excluded steps separated by long periods with no transmitter GPS reception, because we could not differentiate between scenarios in which these periods indicated time spent stationary under cover, or movement under water during which GPS points could not be recorded. We used random intercepts for turtle ID to model inter-individual behavioural variation, and to account for multiple observations per turtle. We compared turning angles and speeds between habitats using Tukey corrected pair-wise comparisons.

\section{Temperature}

We tested the hypothesis that Phragmites and Typha limit turtles' diurnal access to thermal resources (i.e. exposure to sunshine) due to increased shading, which predicts that turtles will have lower diurnal shell temperatures on average when using Typha or Phragmites, compared to other habitat types. We compared shell temperatures of turtles in different habitats using temperatures recorded by transmitters at each daytime GPS point (hourly or bi-hourly locations collected from 07:00 to 20:00). We used a generalized additive mixed-effects model to compare turtle shell temperature between habitat types (fixed effect) at different times (smoothed effect of time). We included random intercepts for turtle ID and date to account for repeated measures of each turtle and the changing availability of temperature between days. We used separate models for E. blandingii and C. guttata.

\section{Results}

Characterization of available habitat

Examination of 45 pollen samples from Typha-dominated habitats used by turtles identified all three Typha taxa (Online Resource 1; Table S1; Fig. S1). Although the numbers of Typha precluded an exhaustive investigation into the proportions of each taxon, these data allow us to conclude that, as anticipated (e.g. Kirk et al. 2011a; Freeland et al. 2013; Pieper et al. 2020), the Typha stands in this wetland comprise multiple taxa including the invasive hybrid $T . \times$ glauca. The mean habitat patch size was $322 \pm 34 \mathrm{~m}^{2}$ for habitat available to E. blandingii and $290 \pm 30 \mathrm{~m}^{2}$ for habitat available to $C$. guttata. Dense Phragmites patches (i.e. $>70 \%$ cover) represented $\sim 12 \%$ and $11 \%$ of the minimum available habitat of E. blandingii and C. guttata, respectively (Table 1). Dense Typha stands $(>70 \%$ cover) represented $\sim 21 \%$ and $30 \%$ of the minimum available habitat of E. blandingii and $C$. guttata, respectively (Table 1). 
Habitat selection

At the landscape scale, E. blandingii did not exhibit preference for, or avoidance of, any of the seven habitat types available to them when selecting home ranges from the minimum available habitat. (Fig. 2a). At the home range scale, E. blandingii avoided open land, forest and open water (CI for selection ratios $<$ 1.0; Fig. 2b). They neither avoided nor preferred Typha, Phragmites, shrub and meadow marshes.

Clemmys guttata selected home ranges containing more meadow marsh and less open water than available in simulated, randomly placed home ranges (Fig. 2c). We found no evidence of preference for, or avoidance of, the other habitat types by $C$. guttata at the landscape scale. At the home range scale, $C$. guttata preferred meadow marsh, and avoided forest, open land and open water (Fig. 2d). C. guttata neither avoided nor preferred Phragmites, Typha, or shrub within their home ranges. Compositional and Eigenvector analyses for both species produced similar results (Online Resource 1; Table S2; Table S3; Fig. S2).

\section{Microhabitat selection}

Phragmites density was similar in quadrats used by $E$. blandingii (mean $\pm \mathrm{SE} ; 6.75 \pm 1.17 \mathrm{stems} / \mathrm{m}^{2}$ ) and random quadrats $\left(6.02 \pm 0.85\right.$ stems $/ \mathrm{m}^{2}$; GLMM: $\chi^{2}=0.18, p=0.67$; Fig. 3a). Typha density was similar in E. blandingii quadrats $(9.68 \pm 1.33$ stems/ $\left.\mathrm{m}^{2}\right)$ and random quadrats $\left(11.30 \pm 2.02 \mathrm{stems} / \mathrm{m}^{2}\right.$; GLMM: $\chi^{2}=0.38, p=0.54$; Fig. 3a). There was no evidence that an interaction between Phragmites and Typha density $\left(\chi^{2}=0.67, \mathrm{p}=0.41\right)$ influenced plot choice by E. blandingii.

Phragmites density was similar in C. guttata quadrats $\left(7.08 \pm 1.40 \mathrm{stems} / \mathrm{m}^{2}\right)$ and random quadrats $\left(4.80 \pm 0.92\right.$ stems $/ \mathrm{m}^{2}$; GLMM: $\chi^{2}=1.74, \mathrm{p}=0.19$; Fig. 3b). Typha density was similar in C. guttata quadrats $\left(15.7 \pm 1.57 \mathrm{stems} / \mathrm{m}^{2}\right)$ and random quadrats $\left(16.1 \pm 2.02 \quad\right.$ stems $/ \mathrm{m}^{2} ; \quad$ GLMM: $\chi^{2}=0.001$, $\mathrm{p}=0.97$; Fig. $3 \mathrm{~b}$ ). There was no evidence that an interaction between Phragmites and Typha density $\left(\chi^{2}=0.75, \mathrm{p}=0.39\right)$ influenced plot choice by $C$. guttata.
Movement

Movement speeds and turning angles for E. blandingii and C. guttata were similar in Phragmites and Typha stands compared to other habitat types. Emydoidea blandingii in open land moved at higher speeds than in other habitats $(\mathrm{F}=2.71, \mathrm{df}=6,794, \mathrm{p}=0.01$; Fig. $4 \mathrm{a}$; all other pairwise comparisons $\mathrm{p}>0.05$ ). The turning angles of E. blandingii were similar between steps within Phragmites, Typha, and all other habitat types $(\mathrm{F}=1.22, \mathrm{df}=6,451, \mathrm{p}=0.30$; Fig. 4b). Movement speed of $C$. guttata was similar in all habitat types $(\mathrm{F}=1.02, \mathrm{df}=6,1302, \mathrm{p}=0.41)$. Turning angles of $C$. guttata differed among habitat types $(\mathrm{F}=2.65, \mathrm{df}=6,611, \mathrm{p}=0.02$; Fig. $4 \mathrm{~b})$. Pairwise comparisons of each pair of habitat types suggested that the turning angles of $C$. guttata were slightly lower in meadow marshes $($ mean $=1.92$ radians, 95\% CI: $1.84-2.00$ ) than in Typha patches (mean $=2.12$ radians, $95 \%$ CI: $1.99-2.24$, pairwiseadjusted $\mathrm{p}=0.08$ ), but was not statistically significant following Tukey adjustment of p-values to correct for multiple pairwise comparisons. Clemmys guttata turning angles were similar between all other habitat types (all other pairwise comparisons: $\mathrm{p}>0.20$ ).

\section{Temperature}

Turtles in Phragmites and Typha were not cooler, on average, than turtles in other habitats. There was an effect of habitat type on the shell temperatures of $E$. blandingii $(\mathrm{F}=2.62, \quad \mathrm{df}=6, \quad 1073, \quad \mathrm{p}=0.02$, $\mathrm{n}=1084$ temperature readings; Fig. 5a, b) where turtles in the forest habitat were an estimated $2.9^{\circ} \mathrm{C}$ cooler than turtles in Typha habitat. No other pairwise comparisons between habitats were significant (all other pairwise-adjusted $\mathrm{p}>0.17$ ). There was no effect of habitat type on shell temperatures of $C$. guttata $(\mathrm{F}=1.19, \mathrm{df}=6,1527, \mathrm{p}=0.31, \mathrm{n}=1541$ temperature readings; Fig. 5c, d).

\section{Discussion}

Our results do not support the hypotheses that invasive Phragmites or mixed-species stands of Typha impede the movements or limit thermoregulation of threatened turtles. Previous year-round tracking of turtles allowed estimates of the turtles' complete home 

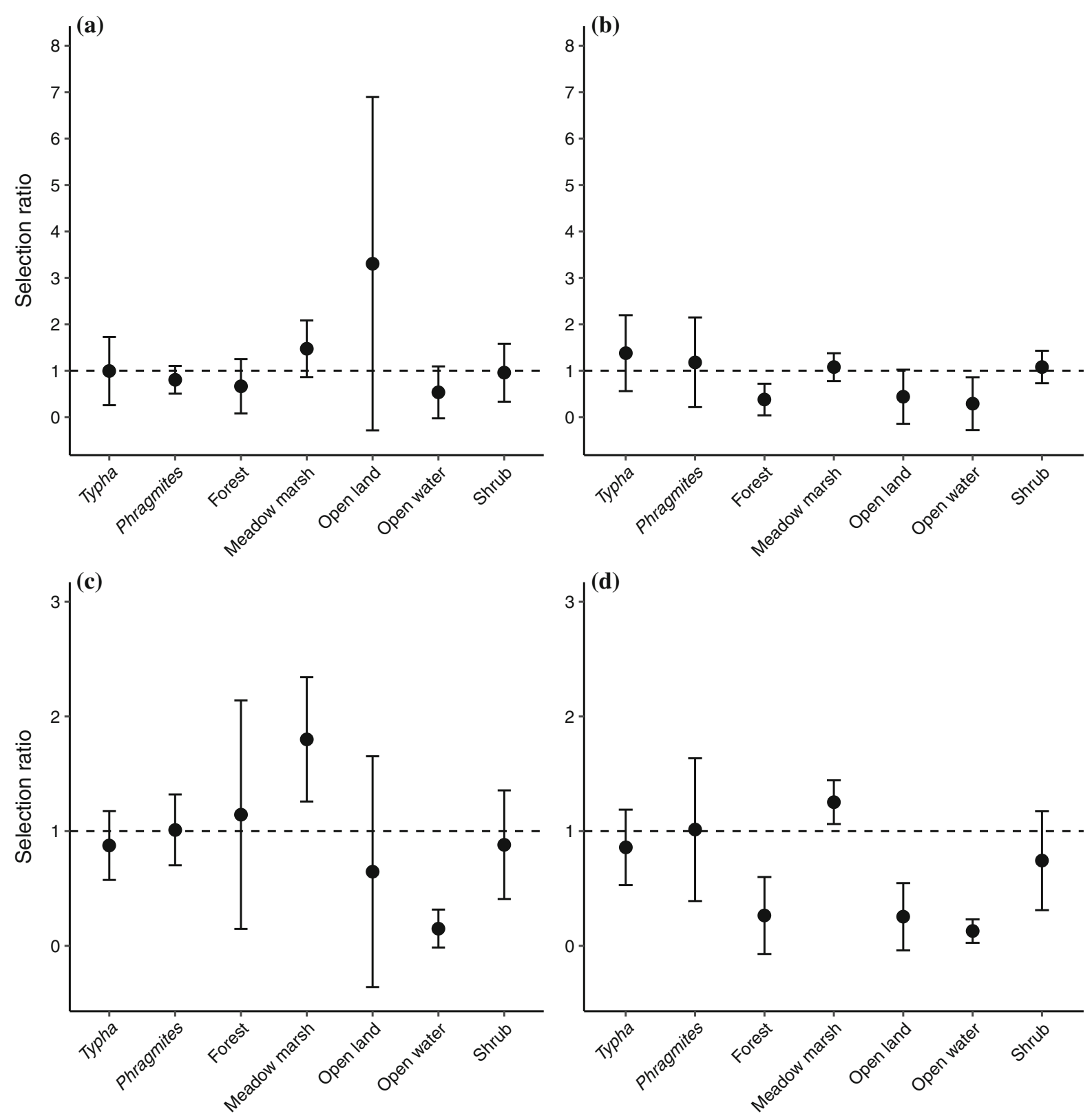

Fig. 2 Selection ratios ( $\pm 95 \%$ confidence intervals) of habitat selection for Emydoidea blandingii (Blanding's turtles; $\mathrm{n}=14$ ) at the landscape scale (a) and the home range scale (b). Selection ratios $( \pm 95 \%$ confidence intervals) of habitat selection for

ranges and seasonal shifts in habitat use, and inferred individual-level avoidance of Phragmites by $E$. blandingii within their home ranges (Markle and Chow-Fraser 2018). We tested two potential mechanisms driving that avoidance, using datasets with high temporal resolution over a short study period spanning

Clemmys guttata (spotted turtles; $\mathrm{n}=12$ ) at the landscape scale (c) and at the home range scale (d). Overlap of selection ratios with the horizontal dashed line indicates no selection or avoidance.

the time of greatest activity for temperate freshwater turtles. Stands of Phragmites and Typha did not restrict the movements of mature, active E. blandingii or C. guttata, and use of these stands did not result in cooler shell temperatures than use of other wetland habitat types. We also found no evidence that density 

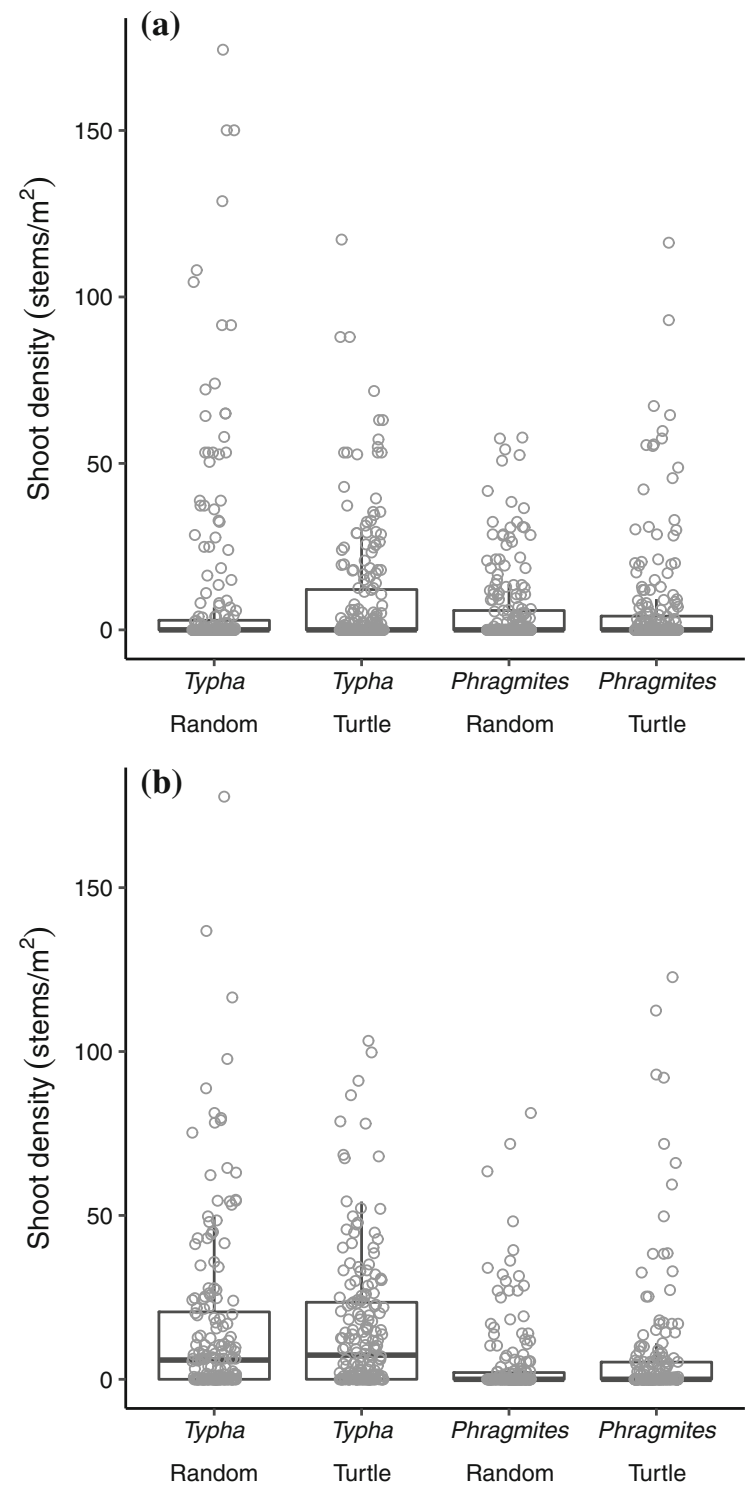

Fig. 3 Shoot density (stems $/ \mathrm{m}^{2}$ ) of Phragmites australis and Typha measured in $4 \mathrm{~m}^{2}$ quadrats was similar in quadrats used by turtles, compared to randomly selected quadrats within the turtle's home ranges, for (a) Emydoidea blandingii (Blanding's turtles; $\mathrm{n}=200$ used, 200 random quadrats) and (b) Clemmys guttata (spotted turtles; $\mathrm{n}=180 \mathrm{used}, 180$ random quadrats)

of Phragmites or Typha influenced turtle's use of these habitats. Our results suggest that turtle avoidance of dense macrophytes is not the result of physical barriers or inadequate thermal conditions, and further research should test other potential explanations. From the perspective of managing biological invasions, our study demonstrates regular use of invasive Phragmites
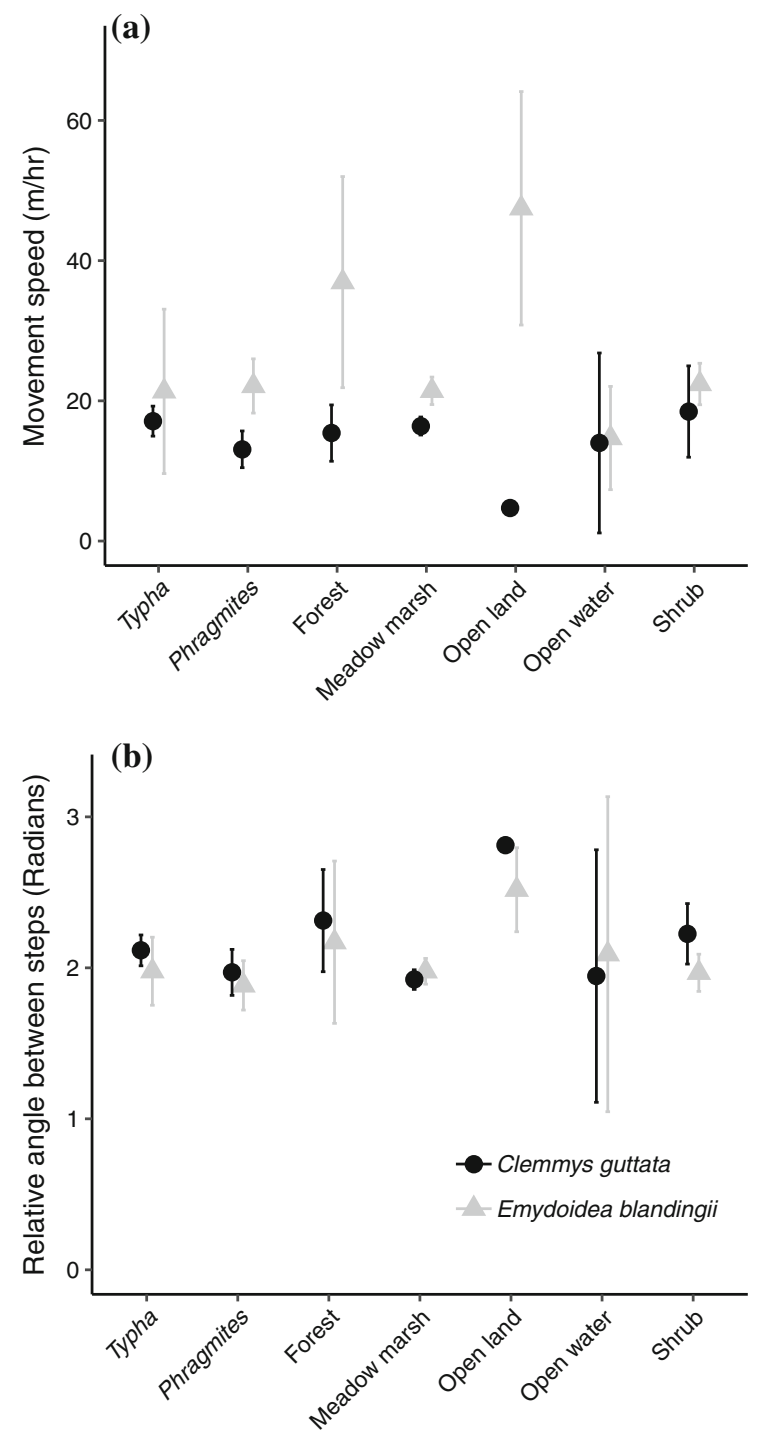

Fig. 4 The mean and 95\% confidence intervals for (a) movement speed and (b) turning angles for Emydoidea blandingii (Blanding's turtles; $\mathrm{n}=14$ ) and Clemmys guttata (spotted turtles; $n=12$ ) in seven habitat types in a southern Ontario wetland

and Typha stands by endangered E. blandingii and $C$. guttata. This finding has implications for the management of invasive macrophytes in wetlands where endangered turtles are present, as control efforts should mitigate potential harm to turtles.

Our results provide a data-rich snapshot of activeseason habitat use by $C$. guttata and E. blandingii. However, our study period captured only a part of the turtles' yearly cycle, and habitat selection varies among seasons. We initially intended to track turtles 

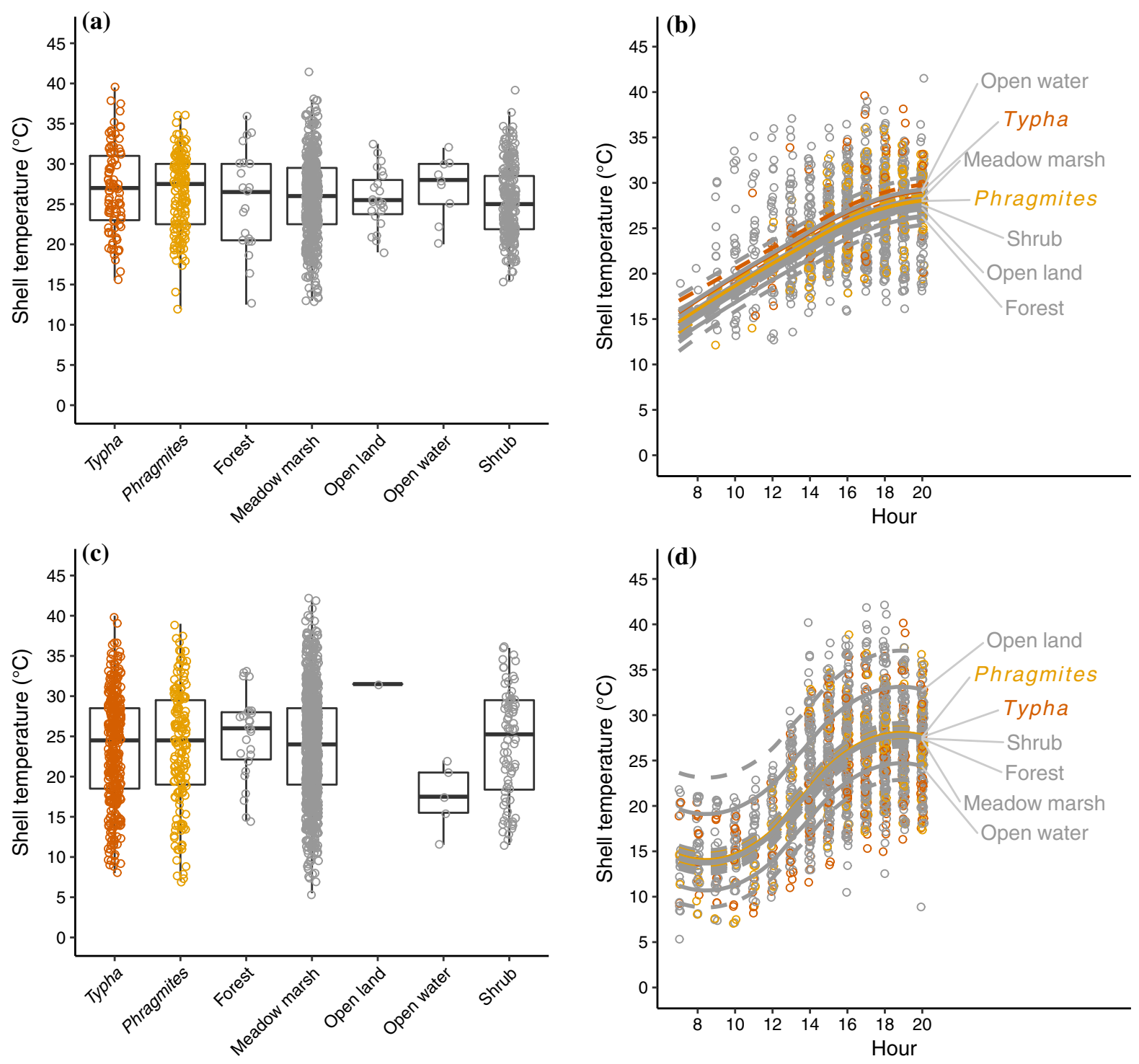

Fig. 5 Turtle shell temperatures of Emydoidea blandingii (Blanding's turtles; $\mathrm{n}=1084$ temperature readings) in seven habitat types (a) and comparing changing temperatures through the day (b). Turtle shell temperatures of Clemmys guttata

to over-wintering sites and continue our study for an entire year, to capture seasonal variation in habitat selection. Unfortunately, the transmitters we used stopped working much earlier than we expected (i.e. stopped recharging and holding their charge). The active season of freshwater turtles is often divided into 'behavioural' seasons (i.e., emergence from hibernation, nesting, post-nesting, overwintering;Rasmussen and Litzgus 2010; Markle and Chow-Fraser 2014). Different biological and behavioural needs related to

(spotted turtles; $\mathrm{n}=1541$ temperature readings) in seven habitat types (c) and comparing changing temperatures through the day (d). Solid lines are model predictions for each habitat. Dashed lines are $\pm 1 \mathrm{SE}$

mating and thermoregulation are directly linked to specific habitat types used during different 'behavioural' seasons (Joyal et al 2001; Litzgus and Mousseau 2004; Beaudry et al 2009), and previous studies have stressed the importance of the temporal scale in assessing habitat selection by turtles. We have not attempted to generalize our results to other seasons, as we did not capture the full annual cycle of E. blandingii or C. guttata. Instead, we used the high frequency of relocations in our dataset to test two 
potential mechanisms driving active-season habitat selection in invaded habitats.

Autocorrelation between relocations is widespread in tracking and habitat selection studies (Fieberg et al 2010), but can be accounted for with appropriate analytical approaches. Autocorrelation between successive relocations is unlikely to have affected the conclusions from our habitat selection analyses because we recorded turtles moving up to $208 \mathrm{~m}$ within $0.5 \mathrm{~h}$, which would allow turtles to move between habitat types based on the mean habitat patch size in our study area for each species. Our results demonstrate that invasive Phragmites and mixedspecies stands of Typha can provide suitable summer habitat for E. blandingii and C. guttata when these habitats are embedded in a larger matrix of available habitat types.

We also acknowledge that turtle use of macrophyte stands may be influenced by differences among wetlands, including the distribution of macrophyte stands within the available turtle habitat. Habitat selection documented for a species at one or a few sites is often generalized across sites or regions during conservation planning (e.g. COSEWIC 2014, 2016b), yet our results differ slightly from those obtained by Markle and Chow-Fraser (2018) in the same wetland. Variation exists not only among wetlands, but also among years (for example, as shifting water levels alter the depth of coastal wetlands). Water levels at our study site were relatively low in 2011 and 2013, when turtles were tracked by Markle and Chow-Fraser (2018). In 2018 when we tracked turtles at the same site, the water level was at least $0.5 \mathrm{~m}$ higher, which may have made macrophyte stands more accessible, and ongoing erosion, invasion by macrophytes, and treatment of invasive macrophytes had changed the shape and habitat composition of the wetland. The effects of shifting water levels and erosion on habitat use by turtles in coastal wetlands deserves further study. Finally, while our data suggest that turtles at our study site use invasive macrophyte stands, at least during their peak active season, our study site was invaded over a decade ago. The responses of turtles to invasion (i.e. shifts in habitat use in response to rapidly changing habitat composition) deserves robust analysis, as also suggested by Markle and Chow-Fraser (2018).

Emydoidea blandingii are relatively large turtles, (adult carapace length between 150 and $240 \mathrm{~mm}$;
Tyning 1990; Congdon et al. 1993). In our study, they showed no evidence of avoiding Phragmites or Typha, nor a clear preference for any habitat types when they chose a home range or moved between locations within their home range. The smaller $C$. guttata (max. carapace length approx. 130 mm;Tyning 1990; Ernst et al. 1994; Litzgus 2006) also did not avoid Phragmites or Typha stands. However, C. guttata showed a preference for meadow marshes within their home ranges, as previously reported (Rasmussen and Litzgus 2010). Home range size varies widely among individual E. blandingii (between 12 and 60 ha in Canada; (COSEWIC 2016b), but E. blandingii home ranges are generally much larger than those of $C$. guttata (between 0.7 and 8.8 ha; COSEWIC 2014). Thus, E. blandingii may tolerate more habitat loss within their larger home ranges before losing access to a particular habitat type, while the smaller home ranges of $C$. guttata may leave them more vulnerable to loss of particular, key habitats (e.g. meadow marshes).

Clemmys guttata may prefer meadow marshes because these are structurally complex habitats which provide access to shallow water, a range of basking sites, and high densities of aquatic and emergent vegetation (Rasmussen and Litzgus 2010). Meadow marshes may also harbour relatively high concentrations of prey, such as juvenile amphibians (Fell et al 2003; Meyer 2003). Invasive Phragmites and T. × glauca both tend to replace meadow marsh habitats (Wilcox et al 2003; Frieswyk and Zedler 2007; Catling and Mitrow 2011; Markle and Chow-Fraser 2018), which could reduce overall habitat quality for $C$. guttata even if the turtles do not avoid the Phragmites and Typha stands themselves. Additional research is needed to determine the differences in resource availability and quality in invaded versus non-invaded habitats used by freshwater turtles with different spatial and biological requirements.

Given that invasive Phragmites and Typha do not provide a barrier to movement, or limit access to thermal resources, further research should test alternate hypotheses to explain the avoidance of these stands observed in previous research (Markle and Chow-Fraser 2018). It is possible that these stands provide reduced foraging opportunities compared to other habitat types (Mifsud 2014; Markle and ChowFraser 2018). Access to food resources can influence habitat selection by turtles (Rasmussen and Litzgus 
2010), as turtles require sufficient food during the spring and summer to fuel their seasonal metabolic activities (e.g., growth, reproduction and storage), and prepare for brumation (Congdon 1989). However, Phragmites patches can support aquatic invertebrates, fish, and amphibians (Fell et al 1998, 2003; Angradi et al 2001; Meyer 2003), all of which are prey for $E$. blandingii and C. guttata (Lagler 1943; Kofron and Schreiber 1985; Rowe 1992; Rasmussen et al 2009).

Although Phragmites stands are often home to a myriad of prey suitable for turtles, additional investigations have concluded that these invasive plants are detrimental to turtles. For example, the replacement of shallow aquatic habitats and mixed meadow marshes by invasive Phragmites was considered a potential driver of extirpation of $C$. guttata at Point Pelee National Park, Ontario (Browne and Hecnar 2007; Markle et al 2018). The extent of Phragmites- and Typha-dominated habitats at our study site might not have reached a threshold that critically limits turtles' access to meadow marshes or other key habitats. Our study was not designed to test whether there is a threshold proportion of meadow marsh habitat that $C$. guttata require within their home ranges, below which a population may not persist. Monitoring the trends and distributions of turtle populations in relation to the expansion of Phragmites and T. $\times$ glauca is necessary before we can determine whether the spread of invasive Phragmites and Typha correlates with the declines of freshwater turtles, and if so, whether there is a threshold beyond which Phragmites and T. $\times$ glauca expansion cause turtle populations to decline.

Although we found no evidence for negative impacts on turtle habitat in this study, invasive Phragmites and Typha do impact some taxa, and can modify wetland structure and function (Tulbure and Johnston 2010; Mitchell et al 2011; Lishawa et al 2014; Lawrence et al 2016; Robichaud and Rooney 2017; Yuckin and Rooney 2019). Coastal wetlands in the Laurentian Great Lakes host high biodiversity and provide a range of ecosystem services (Sierszen et al 2012), and control of invasive macrophytes may be required to protect these. Macrophytes such as Phragmites and $T . \times$ glauca can be controlled mechanically by rolling, mowing and cutting, and are often also treated with herbicides such as glyphosate or imazapyr (Mozdzer et al 2008; Hazelton et al 2014; Wagner et al 2017; Judd and Francoeur 2019). Wetlands invaded by Phragmites and Typha are often repeatedly colonized because populations of these taxa can expand through both seed and rhizome dispersal (Kirk et al 2011b; Pieper et al 2020). Management of invasive macrophytes is therefore an ongoing process.

One objective of controlling invasive Phragmites and Typha is to protect coastal wetland habitats for the native species that rely on them. Understanding how control measures might instead inadvertently harm native species can inform control efforts and thus reduce risk to endangered turtles and other species using invaded habitats. Mechanical control and some herbicide application methods require the use of machinery that is heavy enough to injure turtles or other non-target species, as has been observed at some control sites (Cross 2009; Zarnetske et al. 2010; Howey and Roosenburg 2013; S. Gillingwater, pers. comm.). Limiting the use of heavy machinery in macrophyte stands to the winter months may reduce the risk of encountering turtles. Over-wintering turtles require access to water with specific environmental characteristics that will not freeze solid (Litzgus et al 1999; Edge et al 2009), which macrophyte stands in shallow water may not provide, but the risk of encountering and potentially harming overwintering turtles cannot be completely eliminated. Control measures that are undertaken during the winter months should plan for potential encounters with overwintering turtles, and ideally, identify local overwintering sites ahead of time (i.e. through telemetry), so that these can be avoided. Finally, from the perspective of turtle habitat restoration in invaded areas, restoration of meadow marsh habitats is likely to benefit endangered species such as C. guttata.

Acknowledgements We are grateful to Lucy Brown, Jonathan Chu, Ian Fortin, Jennifer Larkin, Matthew Levac, Sasha Newar, Elyse Perrault, Gavin Prince-Badke, Brittany Talarico, Kat Tisshaw, Verena Sesin, Allison Vanderpas, Valerie Von Zuben and staff at Ontario Parks for assistance in the field. Jeff Bowman, Patricia Chow-Fraser, Chantel Markle, Joe Northrup, Erica Nol, Connor Thompson, and the Trent University MaDGIC Unit provided statistical advice and helpful feedback. Constructive suggestions from three anonymous reviewers greatly improved the manuscript. Finally, we acknowledge that the fieldwork for this study was conducted on the traditional territories of the Attiwonderonk, and we gratefully acknowledge the historic and ongoing contributions of First Nations in stewardship of wildlife around the Laurentian Great Lakes. 
Author contributions Siow Yan Angoh, Christina Davy and Joanna Freeland conceived the study and secured funding; Christina Davy and Joanna Freeland co-supervised Siow Yan Angoh (MSc project); Siow Yan Angoh, James Paterson and Christina Davy conducted field work, Siow Yan Angoh and James Paterson performed statistical analyses; Prabha Rupasinghe did remote sensing-based image classification; Siow Yan Angoh wrote the first version of the manuscript and all authors contributed to editing the final version.

Funding This study was funded by the Ontario Ministry of Natural Resources and Forestry (SARSF_92_18_TU1), by Wildlife Preservation Canada and a MITACS Accelerate grant from the Government of Canada, and by Discovery Grants from the National Science and Engineering Research Council of Canada to Christina Davy and Joanna Freeland.

Availability of data and materials The agencies authorizing the wildlife research in this study require us to maintain the specific location data as sensitive data. However, anonymized data and all code for analyses are available at https://osf.io/ um $7 \mathrm{z} 5 /$.

\section{Declarations}

Conflict of interest The authors declare that they have no conflict of interest.

Ethics approval We captured turtles during the course of a long-term mark-recapture study. All methods were approved by the Animal Care Committee at Trent University (24900), by the Wildlife Animal Care Committee of the Ontario Ministry of Natural Resources and Forestry (18-291), and by a research authorization from Ontario Parks.

\section{Consent to participate NA.}

Consent for publication All authors consent to the publication being submitted for peer review.

Code availability All code for analyses are available at https://osf.io/um7z5/.

Open Access This article is licensed under a Creative Commons Attribution 4.0 International License, which permits use, sharing, adaptation, distribution and reproduction in any medium or format, as long as you give appropriate credit to the original author(s) and the source, provide a link to the Creative Commons licence, and indicate if changes were made. The images or other third party material in this article are included in the article's Creative Commons licence, unless indicated otherwise in a credit line to the material. If material is not included in the article's Creative Commons licence and your intended use is not permitted by statutory regulation or exceeds the permitted use, you will need to obtain permission directly from the copyright holder. To view a copy of this licence, visit http://creativecommons.org/licenses/by/4.0/.

\section{References}

Aebisher NJ, Robertson PA, Kenward RE (1993) Compositional analysis of habitat use from animal radio-tracking data. Ecology 74:1313-1325. https://doi.org/10.2307/ 1940062

Angradi TR, Hagan SM, Able KW (2001) Vegetation type and the intertidal macroinvertebrate fauna of a brackish marsh: Phragmites vs. Spartina Wetlands 21:75-92. https://doi. org/10.1672/0277-5212(2001)021[0075:vtatim]2.0.co;2

Bansal S, Lishawa SC, Newman S et al (2019) Typha (Cattail) invasion in North American wetlands: biology, regional problems, impacts, ecosystem services, and management. Wetlands 39:645-684. https://doi.org/10.1007/s13157019-01174-7

Bates DM, Maechler M, Bolker B, Walker S (2015) Fitting linear mixed-effects models using lme4. J Stat Softw 67:1-48. https://doi.org/10.18637/jss.v067.i01

Beaudry F, DeMaynadier PG, Hunter ML (2009) Seasonally dynamic habitat use by spotted (Clemmys guttata) and Blanding's turtles (Emydoidea blandingii) in Maine. J Herpetol 43:636-645. https://doi.org/10.1670/08-127.1

Bellavance ME, Brisson J (2010) Spatial dynamics and morphological plasticity ofcommon reed (Phragmites australis) and cattails (Typha sp.) in freshwater marshes and roadside ditches. Aquat Bot 93:129-134. https://doi. org/10.1016/j.aquabot.2010.04.003

Benoit LK, Askins RA (1999) Impact of the spread of Phragmites on the distribution of birds in Connecticut tidal marshes. Wetlands 19:194-208. https://doi.org/10.1007/ bf03161749

Bernstein NP, Mclean EB (1980) Nesting of red-winged blackbirds in cattails and common reed grass in mentor marsh. Ohio J Sci 80:14-19

Bolton RM, Brooks RJ (2010) Impact of the seasonal invasion of Phragmites australis (common reed) on turtle reproductive success. Chelonian Conserv Biol 9:238-243. https://doi.org/10.2744/CCB-0793.1

Boyce MS (1978) Climatic variability and body size variation in the muskrats (Ondatra zibethicus) of North America. Oecologia 19:1-19. https://doi.org/10.1007/BF00344567

Browne CL, Hecnar SJ (2007) Species loss and shifting population structure of freshwater turtles despite habitat protection. Biol Conserv 138:421-429. https://doi.org/10. 1016/j.biocon.2007.05.008

Calenge C (2006) The package adehabitat for the R software: a tool for the analysis of space and habitat use by animals. Ecol Modell 197:516-519. https://doi.org/10.1016/j. ecolmodel.2006.03.017

Calenge C, Dufour AB (2006) Eigenanalysis of selection ratios from animal radio-tracking data. Ecology 87:2349-2355. https://doi.org/10.1890/00129658(2006)87[2349:EOSRFA]2.0.CO;2

Campbell KL, MacArthur RA (1994) Digestibility and assimilation of natural forages by muskrat. J Wildl Manage 58:633-641. https://doi.org/10.2307/3809676

Catling PM, Mitrow G (2011) The recent spread and potential distribution of Phragmites australis subsp. australis in Canada. Can Field-Naturalist 125:95-104. https://doi.org/ 10.22621/cfn.v125i2.1187 
Chambers RM, Meyerson LA, Saltonstall K (1999) Expansion of Phragmites australis into tidal wetlands of North America. Aquat Bot 64:261-273. https://doi.org/10.1016/ S0304-3770(99)00055-8

Ciotir C, Freeland J (2016) Cryptic intercontinental dispersal, commercial retailers, and the genetic diversity of native and non-native cattails (Typha spp.) in North America. Hydrobiologia 768:137-150. https://doi.org/10.1007/ s10750-015-2538-0

Ciotir C, Kirk H, Row JR, Freeland JR (2013) Intercontinental dispersal of Typha angustifolia and T. latifolia between Europe and North America has implications for Typha invasions. Biol Invasions 15:1377-1390. https://doi.org/ 10.1007/s10530-012-0377-8

Congdon JD (1989) Proximate and evolutionary constraints on energy relations of reptiles. Physiol Zool 62:356-373

Congdon JD, Dunham AE, Van Loben Sels RC (1993) Delayed sexual maturity and demographics of Blanding's Turtles (Emydoidea Blandingii): implications for conservation and management of long-lived organisms. Conserv Biol 7:826-833. https://doi.org/10.1046/j.1523-1739. 1993.740826.x

Cook CE, McCluskey AM, Chambers RM (2018) Impacts of invasive Phragmites australis on diamondback terrapin nesting in Chesapeake Bay. Estuaries Coasts 41:966-973. https://doi.org/10.1007/s12237-017-0325-z

COSEWIC (2016a) COSEWIC assessment and status report on the spiny softshell Apalone spinifera in Canada. Committee on the Status of Endangered Wildlife in Canada, Ottawa, xiii +38 pp https://species-registry.canada.ca/ index-en.html

COSEWIC (2014) COSEWIC assessment and status report spotted turtle Clemmys guttata in Canada. Committee on the Status of Endangered Wildlife in Canada, Ottawa, xiv + $74 \mathrm{pp}$ https://species-registry.canada.ca/index-en.html

COSEWIC (2016b) COSEWIC assessment and update status report on the Blanding's turtle Emydoidea blandingii in Canada. Committee on the Status of Endangered Wildlife in Canada, Ottawa, xix +110 pp.https://species-registry. canada.ca/index-en.html

Cross MD (2009) Responses of the eastern massasauga rattlesnake (Sistrurus catenatus catenatus) to prescribed fire in southwestern Michigan wetland praires. Master's thesis,. Central Michigan University

Dueñas MA, Ruffhead HJ, Wakefield NH et al (2018) The role played by invasive species in interactions with endangered and threatened species in the United States: a systematic review. Biodivers Conserv 27:3171-3183. https://doi.org/ 10.1007/s10531-018-1595-x

Early R, Bradley BA, Dukes JS et al (2016) Global threats from invasive alien species in the twenty-first century and national response capacities. Nat Commun 7:12485. https://doi.org/10.1038/ncomms12485

Edge CB, Steinberg BD, Brooks RJ, Litzgus JD (2009) Temperature and site selection by Blanding's Turtles (Emydoidea blandingii) during hibernation near the species' northern range limit. Can J Zool 87:825-834. https:// doi.org/10.1139/z09-073
Environment and Climate Change Canada (2018a) Recovery strategy for the spotted turtle (Clemmys guttata) in Canada. Species at Risk Act Recovery Strategy Series. Environment and Climate Change Canada, Ottawa. ix +61 pp. Ottawa

Environment and Climate Change Canada (2018b) Recovery strategy for the Blanding's turtle (Emydoidea blandingii), Great Lakes / St. Lawrence population, in Canada. Species at Risk Act Recovery Strategy Series. Environment and Climate Change Canada, Ottawa. viii +59 pp

Ernst CH, Lovich JE, Barbour RW (1994) Turtles of the United States and Canada. Smithsonian Inst. Press, Washington

ESRI (2018) ArcMap. Environmental Systems Research Institute, Redlands, CA

Farnsworth EJ, Meyerson LA (2003) Comparative ecophysiology of four wetland plant species along a continuum of invasiveness. Wetlands 23:750-762. https://doi.org/10. 1672/0277-5212(2003)023[0750:CEOFWP]2.0.CO;2

Farrer EC, Goldberg DE (2009) Litter drives ecosystem and plant community changes in cattail invasion. Ecol Appl 19:398-412. https://doi.org/10.1890/08-0485.1

Fell PE, Warren RS, Light JK et al (2003) Comparison of fish and macroinvertebrate use of Typha angustifolia, Phragmites australis, and treated Phragmites marshes along the lower Connecticut River. Estuaries 26:534-551. https:// doi.org/10.1007/BF02823729

Fell PE, Weissbach SP, Jones DA et al (1998) Does invasion of oligohaline tidal marshes by reed grass, Phragmites australis (Cav.) Trin. ex Steud., affect the availability of prey resources for the mummichog, Fundulus heteroclitus L.? J Exp Mar Bio Ecol 222:59-77. https://doi.org/10.1016/ S0022-0981(97)00138-X

Fieberg J, Matthiopoulos J, Hebblewhite M et al (2010) Correlation and studies of habitat selection: Problem, red herring or opportunity? Philos Trans R Soc B Biol Sci 365:2233-2244. https://doi.org/10.1098/rstb.2010.0079

Freeland J, Ciotir C, Kirk H (2013) Regional differences in the abundance of native, introduced, and hybrid Typha spp. in northeastern North America influence wetland invasions. Biol Invasions 15:2651-2665. https://doi.org/10.1007/ s10530-013-0481-4

Frieswyk CB, Zedler JB (2007) Vegetation change in Great Lakes coastal wetlands: deviation from the historical cycle. J Great Lakes Res 33:366-380. https://doi.org/10.3394/ 0380-1330(2007)33

Gaertner M, Breeyen A, Den, Hui C, Richardson DM (2009) Impacts of alien plant invasions on species richness in mediterranean-type ecosystems: A meta-analysis. Prog Phys Geogr 33:319-338. https://doi.org/10.1177/ 0309133309341607

Gagnon Lupien N, Gauthier G, Lavoie C (2015) Effect of the invasive common reed on the abundance, richness and diversity of birds in freshwater marshes. Anim Conserv 18:32-43. https://doi.org/10.1111/acv.12135

Galatowitsch SM, Anderson NO, Ascher PD (1999) Invasiveness in wetland plants in temperate North America. 
Wetlands 19:733-755. https://doi.org/10.1007/ BF03161781

Geddes P, Grancharova T, Kelly JJ et al (2014) Effects of invasive Typha $\times$ glauca on wetland nutrient pools, denitrification, and bacterial communities are influenced by time since invasion. Aquat Ecol 48:247-258. https://doi. org/10.1007/s10452-014-9480-5

Grace JB, Harrison JS (1986) The biology of Canadian weed. 73. Typha latifolia L., Typha angustifolia L. and Typha $x$ glauca Godr. Can J Plant Sci 66:361-379. https://doi.org/ 10.4141/cjps86-051

Greenberg DA, Green DM (2013) Effects of an invasive plant on population dynamics in toads. Conserv Biol 27:1049-1057. https://doi.org/10.1111/cobi.12078

Hazelton ELG, Mozdzer TJ, Burdick DM et al (2014) Phragmites australis management in the United States: 40 years of methods and outcomes. AoB Plants 6:1-19. https://doi.org/10.1093/aobpla/plu001

Hershner C, Havens KJ (2008) Managing invasive aquatic plants in a changing system: Strategic consideration of ecosystem services. Conserv Biol 22:544-550. https://doi. org/10.1111/j.1523-1739.2008.00957.x

Hirtreiter JN, Potts DL (2012) Canopy structure, photosynthetic capacity and nitrogen distribution in adjacent mixed and monospecific stands of Phragmites australis and Typha latifolia. Plant Ecol 213:821-829. https://doi.org/ 10.1007/s11258-012-0044-2

Holdredge C, Bertness MD (2011) Litter legacy increases the competitive advantage of invasive Phragmites australis in New England wetlands. Biol Invasions 13:423-433. https://doi.org/10.1007/s10530-010-9836-2

Howey CAF, Roosenburg WM (2013) Effects of prescribed fire on the eastern box turtle (Terrapene carolina carolina). Northeast Nat 20:493-497. https://doi.org/10.1656/045. 020.0312

Johnson DH (1980) The comparison of usage and availability measurements for evaluating resource preference. Ecology 61:65-71. https://doi.org/10.2307/1937156

Joyal LA, McCollough M, Hunter MLJ (2001) Landscape ecology approaches to wetland species conservation: a case study of two turtle species in southern Maine. Conserv Biol 15:1755-1762. https://doi.org/10.1046/j.1523-1739.2001. 98574.X

Judd KE, Francoeur SN (2019) Short-term impacts of Phragmites management on nutrient budgets and plant communities in Great Lakes coastal freshwater marshes. Wetl Ecol Manag 27:55-74. https://doi.org/10.1007/ s11273-018-9643-6

Kantrud HA (1986) Effects of vegetation manipulation on breeding waterfowl in prairie wetlands - a literature review. Washington

Keller BEM (2000) Plant diversity in Lythrum, Phragmites, and Typha marshes, Massachusetts, U.S.A. Wetl Ecol Manag 8:391-401. https://doi.org/10.1023/A: 1026505817409

Kettenring KM, Adams CR (2011) Lessons learned from invasive plant control experiments: A systematic review and meta-analysis. J Appl Ecol 48:970-979. https://doi. org/10.1111/j.1365-2664.2011.01979.x
Kirk H, Connolly C, Freeland JR (2011a) Molecular genetic data reveal hybridization between Typha angustifolia and Typha latifolia across a broad spatial scale in eastern North America. Aquat Bot 95:189-193. https://doi.org/10.1016/j. aquabot.2011.05.007

Kirk H, Paul J, Straka J, Freeland JR (2011b) Long-distance dispersal and high genetic diversity are implicated in the invasive spread of the common reed, Phragmites australis (Poaceae), in northeastern North America. Am J Bot 98:1180-1190. https://doi.org/10.3732/ajb.1000278

Kiviat E (2013) Ecosystem services of Phragmites in North America with emphasis on habitat functions. AoB Plants 5:plt008. https://doi.org/10.1093/aobpla/plt008

Kofron CP, Schreiber AA (1985) Ecology of two endangered aquatic turtles in Missouri: Kinosternon flavescens and Emydoidea blandingii. J Herpetol 19:27-40. https://doi. org/10.2307/1564417

Krattinger K (1975) Genetic mobility in Typha. Aquat Bot 1:57-70. https://doi.org/10.1016/0304-3770(75)90007-8

Lagler KF (1943) Food habits and economic relations of the turtles of Michigan with special reference to fish management. Am Midl Nat 29:257-312. https://doi.org/10.2307/ 2420793

Larkin DJ, Freyman MJ, Lishawa SC et al (2012) Mechanisms of dominance by the invasive hybrid cattail Typha $\times$ glauca. Biol Invasions 14:65-77. https://doi.org/10.1007/ s10530-011-0059-y

Lawrence BA, Lishawa SC, Rodriguez Y, Tuchman NC (2016) Herbicide management of invasive cattail (Typha $\times$ glauca) increases porewater nutrient concentrations. Wetl Ecol Manag 24:457-467. https://doi.org/10.1007/s11273015-9471-x

Levine JM, Vilà M, D’Antonio CM et al (2003) Mechanisms underlying the impacts of exotic plant invasions. Proc R Soc B Biol Sci 270:775-781. https://doi.org/10.1098/rspb. 2003.2327

Linz GM, Bleief WJ, Overland JD, Homan JH (1999) Response of invertebrates to glyphosate induced habitat alterations in wetlands. Wetlands 19:220-227. https://doi. org/10.1007/BF03161751

Linz GM, Blixt DC, Bergman DL, Bleier WJ (1996a) Responses of red-winged blackbirds, yellow-headed blackbirds and marsh wrens to glyphosate-induced alterations in cattail density. J F Ornithol 67:167-176. https:// doi.org/10.1007/BF03161751

Linz GM, Blixt DC, Bergman DL, Bleier WJ (1996b) Response of ducks to glyphosate-induced habitat alterations in wetlands. Wetlands 16:38-44. https://doi.org/10. 1007/BF03161751

Linz GM, Homan HJ (2011) Use of glyphosate for managing invasive cattail (Typha spp.) to disperse blackbird (Icteridae) roosts. Crop Prot 30:98-104. https://doi.org/10.1016/ j.cropro.2010.10.003

Lishawa SC, Albert DA, Tuchman NC (2010) Water level decline promotes Typha $\times$ glauca establishment and vegetation change in Great Lakes coastal wetlands. Wetlands 30:1085-1096. https://doi.org/10.1007/s13157-010-0113$\mathrm{z}$ 
Lishawa SC, Jankowski KJ, Geddes P et al (2014) Denitrification in a Laurentian Great Lakes coastal wetland invaded by hybrid cattail (Typha $\times$ glauca). Aquat Sci 76:483-495. https://doi.org/10.1007/s00027-014-0348-5

Litzgus JD (2006) Sex differences in longevity in the spotted turtle (Clemmys guttata). Copeia 2006:281-288. https://doi. org/10.1643/0045-8511(2006)6[281:SDILIT]2.0.CO;2

Litzgus JD, Costanzo JP, Brooks RJ, Lee RE (1999) Phenology and ecology of hibernation in spotted turtles (Clemmys guttata) near the northern limit of their range. Can J Zool Can Zool 77:1348-1357. https://doi.org/10. 1139/cjz-77-9-1348

Litzgus JD, Mousseau T (2004) Home range and seasonal activity of southern spotted turtles (Clemmys guttata): implications for management. Copeia 4:804-817. https:// doi.org/10.1643/CH-04024R1

Manly BFJ, McDonald LL, Thomas DL et al (2002) Resource selection by animals - Statistical design and Analysis for field studies, Second edi. Kluwer academic publisher, London

Markle CE, Chow-Fraser G, Chow-Fraser P (2018) Long-term habitat changes in a protected area: implications for herpetofauna habitat management and restoration. PLoS One 13:1-15. https://doi.org/10.1371/journal.pone.0192134

Markle CE, Chow-Fraser P (2018) Effects of European common reed on Blanding's turtle spatial ecology. J Wildl Manage 82:857-864. https://doi.org/10.1002/jwmg.21435

Markle CE, Chow-Fraser P (2014) Habitat selection by the Blanding's turtle (Emydoidea blandingii) on a protected island in Georgian Bay, Lake Huron. Chelonian Conserv Biol 13:216-226. https://doi.org/10.2744/CCB-1075.1

Martin LJ, Blossey B (2013) The runaway weed: Costs and failures of Phragmites australis management in the USA. Estuaries Coasts 36:626-632. https://doi.org/10.1007/ s12237-013-9593-4

Meyer SW (2003) Comparative use of Phragmites australis and other habitats by birds, amphibians, and small mammals at Long Point, Ontario. Master's thesis,. University of Western Ontario

Meyerson LA, Cronin JT (2013) Evidence for multiple introductions of Phragmites australis to North America: Detection of a new non-native haplotype. Biol Invasions 15:2605-2608. https://doi.org/10.1007/s10530-013-04912

Mifsud DA (2014) A status assessment and review of the herpetofauna within the Saginaw Bay of Lake Huron. J Great Lakes Res 40:183-191. https://doi.org/10.1016/j. jglr.2013.09.017

Minchinton TE, Bertness MD (2003) Disturbance-mediated competition and the spread of Phragmites australis in a coastal marsh. Ecol Appl 13:1400-1416. https://doi.org/ 10.1890/02-5136

Minchinton TE, Simpson JC, Bertness MD (2006) Mechanisms of exclusion of native coastal marsh plants by an invasive grass. J Ecol 94:342-354. https://doi.org/10.1111/ j.1365-2745.2006.01099.x

Mitchell ME, Lishawa SC, Geddes P et al (2011) Timedependent impacts of cattail invasion in a great lakes coastal wetland complex. Wetlands 31:1143-1149. https:// doi.org/10.1007/s13157-011-0225-0

Mozdzer TJ, Hutto CJ, Clarke PA, Field DP (2008) Efficacy of imazapyr and glyphosate in the control of non-native Phragmites australis. Restor Ecol 16:221-224. https://doi. org/10.1111/j.1526-100X.2008.00386.x

Orson RA (1999) A paleoecological assessment of Phragmites australis in New England tidal marshes: changes in plant community structure during the last few millennia. Biol Invasions 1:149-158. https://doi.org/10.1023/A: 1010047731369

Paradis É, Bellavance M, Fontaine B, Brisson J (2014) Interspecific competition for space between wetland plants with clonal growth. Wetlands 34:1003-1012. https://doi. org/10.1007/s13157-014-0564-8

Pebesma EJ, Bivand RS (2005) Classes and methods for spatial data in R. R News 5:9-13

Pieper S, Dorken M, Freeland J (2020) Genetic structure in hybrids and progenitors provides insight into processes underlying an invasive cattail (Typha $\times$ glauca) hybrid zone. Heredity 124:714-725. https://doi.org/10.1038/ s41437-020-0307-y

Quirion B, Simek Z, Dávalos A, Blossey B (2018) Management of invasive Phragmites australis in the Adirondacks: a cautionary tale about prospects of eradication. Biol Invasions 20:59-73. https://doi.org/10.1007/s10530-0171513-2

R Core Team (2018) R: A language and environment for statistical computing. R Foundation for Statistical Computing, Vienna. http://www.R-project.org/

Rasmussen ML, Litzgus JD (2010) Habitat selection and movement patterns of Spotted Turtles (Clemmys guttata): effects of spatial and temporal scales of analyses. Copeia 2010:86-96. https://doi.org/10.1643/CE-09-141

Rasmussen ML, Paterson JE, Litzgus JD (2009) Foraging ecology of spotted turtles (Clemmys guttata) in Ontario, Canada. Herpetol Rev 40:286-288

Renka RJ, Gebhardt A, Eglen S et al (2020) tripack: triangulation of irregularly spaced data. version 1.3-9. https://cran. r-project.org/package $=$ tripack

Robichaud CD, Rooney RC (2017) Long-term effects of a Phragmites australis invasion on birds in a Lake Erie coastal marsh. J Great Lakes Res 43:141-149. https://doi. org/10.1016/j.jglr.2017.03.018

Rogalski MA, Skelly DK (2012) Positive effects of nonnative invasive Phragmites australis on larval bullfrogs. PLoS One doi. https://doi.org/10.1371/journal.pone.0044420

Row JR, Blouin-Demers G (2006) Kernels are not accurate estimators of home-range size for herpetofauna. Copeia 2006:797-802. 8511(2006)6[797:KANAEO]2.0.CO;2

Rowe JW (1992) Dietary habits of the Blanding's turtle (Emydoidea blandingii) in northeastern Illinois. J Herpetol 26:111-114. https://doi.org/10.2307/1565040

Sala OE, Chapin FS, Armesto JJ et al (2000) Global biodiversity scenarios for the year 2100. Science 287:1770-1774. https://doi.org/10.1126/science.287.5459. 1770 
Saltonstall K (2002) Cryptic invasion by a non-native genotype of the common reed, Phragmites australis, into North America. Proc Natl Acad Sci 99:2445-2449. https://doi. org/10.1073/pnas.032477999

Saltonstall K, Peterson PM, Soreng RJ (2004) Recognition of Phragmites australis subsp. americanus (Poaceae: Arundinoideae) in North America: evidence from morphological and genetic analyses. Contrib to Bot 21:683-692

Sierszen ME, Morrice JA, Trebitz AS, Hoffman JC (2012) A review of selected ecosystem services provided by coastal wetlands of the Laurentian Great Lakes. Aquat Ecosyst Heal Manag 15:92-106. https://doi.org/10.1080/ 14634988.2011.624970

Stewart PS, Hill RA, Stephens PA et al (2021) Impacts of invasive plants on animal behaviour. Ecol Lett. https://doi. org/10.1111/ele.13687

Travis SE, Marburger JE, Windels S, Kubátová B (2010) Hybridization dynamics of invasive cattail (Typhaceae) stands in the western Great Lakes region of North America: A molecular analysis. J Ecol 98:7-16. https://doi.org/10. 1111/j.1365-2745.2009.01596.x

Tuchman NC, Larkin DJ, Geddes P et al (2009) Patterns of environmental change associated with Typha $x$ glauca invasion in a Great Lakes coastal wetland. Wetlands 29:964-975. https://doi.org/10.1672/08-71.1

Tulbure MG, Johnston CA (2010) Environmental conditions promoting non-native Phragmites australis expansion in great lakes coastal wetlands. Wetlands 30:577-587. https:// doi.org/10.1007/s13157-010-0054-6

Tulbure MG, Johnston CA, Auger DL (2007) Rapid invasion of a Great Lakes coastal wetland by non-native Phragmites australis and Typha. J Great Lakes Res 33:269-279. https://doi.org/10.3394/0380-1330(2007)33

Tyning TF (1990) A Guide to Amphibians and Reptiles. Stokes Nature Guides. Little, Brown and Co., Boston

Vaccaro LE, Bedford BL, Johnston CA (2009) Litter accumulation promotes dominance of invasive species of cattails (Typha spp.) in Lake Ontario wetlands. Wetlands 29:1036-1048. https://doi.org/10.1672/08-28.1

Van Der Putten WH (1997) Die-back of Phragmites australis in European wetlands: An overview of the European research programme on reed die-back and progression (1993-1994). Aquat Bot 59:263-275. https://doi.org/10. 1016/S0304-3770(97)00060-0

van Dijk PP (2011) Clemmys guttata (errata version published in 2016). IUCN Red List Threat Species e.T4968A97411228. https://doi.org/10.2305/IUCN.UK. 2011-1.RLTS.T4968A11103766.en

van Dijk PP, Rhodin AGJ (2011) Emydoidea blandingii. IUCN red List Threat species e.T7709A155088836. https://doi.
org/10.2305/IUCN.UK.2011-1.RLTS.T7709A155088836. en

Vilà M, Espinar JL, Hejda M et al (2011) Ecological impacts of invasive alien plants: A meta-analysis of their effects on species, communities and ecosystems. Ecol Lett 14:702-708. https://doi.org/10.1111/j.1461-0248.2011. 01628.x

Vilà M, Espinar JL, Hejda M et al (2010) Seasonal abundance and species richness of birds in common reed habitats in Lake Erie. J Great Lakes Res 26:46-61. https://doi.org/10. 2193/2008-467

Wagner V, Antunes PM, Irvine M, Nelson CR (2017) Herbicide usage for invasive non-native plant management in wildland areas of North America. J Appl Ecol 54:198-204. https://doi.org/10.1111/1365-2664.12711

Weinstein MP, Balletro JH (1999) Does the common reed, Phragmites australis, affect essential fish habitat? Estuaries 22:793-802. https://doi.org/10.2307/1353112

Weis JS, Weis P (2003) Is the invasion of the common reed, Phragmites australis, into tidal marshes of the eastern US an ecological disaster? Mar Pollut Bull 46:816-820. https://doi.org/10.1016/S0025-326×(03)00036-5

Wilcove DS, Rothstein D, Dubow J et al (1998) Quantifying threats to imperiled species in the United States. Bioscience 48:607-615. https://doi.org/10.2307/1313420

Wilcox KL, Petrie SA, Maynard LA, Meyer SW (2003) Historical distribution and abundance of Phragmites australis at Long Point, Lake Erie, Ontario. J Great Lakes Res 29:664-680. https://doi.org/10.1016/S03801330(03)70469-9

Windham L, Meyerson LA (2003) Effects of common reed (Phragmites australis) expansions on nitrogen dynamics of tidal marshes of the northeastern U. $\mathrm{S}$ Estuaries 26:452-464. https://doi.org/10.1007/BF02823722

Wynia AG (2019) Fish and invertebrate use of invasive Phragmites in a Great Lakes freshwater delta. Master's thesis,. Trent University

Yuckin S, Rooney R (2019) Significant increase in nutrient stocks following Phragmites australis invasion of freshwater meadow marsh but not of cattail marsh. Front Environ Sci 7:1-16. https://doi.org/10.3389/fenvs.2019. 00112

Zarnetske PL, Seabloom EW, Hacker SD (2010) Non-target effects of invasive species management: beachgrass, birds, and bulldozers in coastal dunes. Ecosphere. https://doi.org/ 10.1890/ES10-00101.1

Publisher's Note Springer Nature remains neutral with regard to jurisdictional claims in published maps and institutional affiliations. 